れ，film 自身の粒状性にはほにんじ变化が認められなか った。 また変化の程度は，ガンマ值の変化の割合々， screen-mottleの寄与分によって左右されて来ると考元ら れる.

\section{4. シネ自動現像機の管理について}

国立循環器病センター診療放射線部

○中山一彦・若松孝司・横山博典 佐合正義・今出川和世

シネフィルムを用いた，血管造影検査は，そのほ之ん ぞが検查終了後汇現像処理され，乙の検查の特殊性，又 患者の負担の大きい事等，あらゆる面加ら再検䍒は不可 能汇近く，フィルムの現像処理でのミスは助るされない。 そこで毎日の濃度管理を含めた，シネ自現機の管理が必 要となる，当センターでは，繁朝， $\mathrm{T}$ 社製センシメトメ 一タでテストピースを作製し，2台の自現機に通し，特 性曲線加ら, その特性值を求如, 每日の変化について, 又2 台の自現機間のバラッキの有無について管理してい る. 女周期的な，処理タンク及びラックの清掃を行ない, 污れのひどい駆動口ーラを取り換えるなどして，最良の 写の仕上がりにしようと日々つとめている.

\section{5. 自動現像機スタンバイ方式における 新温度制御方} 式について

\section{大阪大学医学部附属病院中央放射線部 ○森口武彦・中西省三・高橋秀彰 山口和也 \\ 小西六写真工業株式会社 豊田 稔}

〔目的〕救急施設で常時自現機を使用できるセイビン グ・ユニットが穾用化されているが，(1)常て液温が高温 保持で処理液の酸化が激しい.(2)30分でとの駆動で各ク ロスオーバー・ローラの摩耗と処理液の付着と污染で写 真の画質が低下，(3)30分ごとに5 分間駆動は不経済之言 う問題点を待期温度の 2 段階温度制御方式を検討した。

〔結果〕スタンバイ洔間を無限大にし低温維持回路に より，ヒータと連動で現像と定着の循環ポンプを駆動し 連続駆動をしない，以上より，(1)現像液疲学の低减，(2) 循環ポンプの発熱による液温上昇の防止，(3)スタンバイ 使用時の水洗水バイパスの不要化之流洗水の節約, (4)循 環ポンプの寿命延長が上げられ写真の仕上りも良い結果 を得た。

\section{6. 自動現像機による現像処理と写真効果について} 大阪大学宝学部附属病院中央放射線部

O松本光弘・鿆延良治・坂下湄治 川本清澄 $\cdot$ 前田大助・山口和也 高橋秀彰・㷊 嘉信
〔目的〕現像時間と処理温度の雨方を独立して変化さ せるととのできる自現機を使用して，現像温度と処理時 間の組合せを変化させること亿よる，X線写真の写真効 果にどのような影響を及ぼすかを種々の画像評洒法を用 いて検討した.

〔結果】(1)バーガズファントムなどの視覚的評価法に 执いては有意な差は見马れなかったが，特性曲線， RM $\mathrm{S}$ 等の物理的評佂法に扔りては差がみられた。 (2)自現機 用迅速フィルム，処理液を使用する限り低温長時閐現像 に大きな期待を加りるのは無理であ万う。 (3)現像処理条 件は目的とする撮影領域に応じたシステムで検討を加え ていかなければならないだるうと思われる。

\section{7. 現像温度の微小被写体識別レベルへの影響}

\section{更生病院放射線技術科}

○岩佐 彰: 後藤良蔵・三浦明展 沢田道人

現像温度を変化させせた場合，写真のコントラストと粒 状性が変化し，低コントラストな微小被写体の識別に影 響が出るすのと考えら机る。：そこで高感度化化伴心微小 被写体の検出能が特に問題となる希土類システム (NG4 -RXO・G8-AO) を使用し, 90 秒処理, $34.5^{\circ} \mathrm{C} \cdot 33.5^{\circ} \mathrm{C}$. $32.5^{\circ} \mathrm{C}$ 各温度について物理的データを踏まえ, ハウレ ットチャートを用いた視覚的評価を行ない検討した。(ま とめ) ‥1）システムにより良化の仕方は異なるが、コン トコントラントは多少犠牲にしても，粒状性を重視した 処理温度の方が微小被写体の識別レベルは问上する。

2）識別レベルは主に粒状性に支配されるが, 増感紙のレ スポンスも識別に関与している.

358. エントロピーによる現像能の評価

山口大学医学部附属病院放射線部

○山根 智・大塚炤義・宇津見博基

横山!敬・中西 敬

〔目的〕今回，われわれは，処理時間 (90秒と3.5分)， 自現機の種類 ( $\left(3\right.$ 機種)，現像温度 $\left(29 \sim 37^{\circ} \mathrm{C}\right)$ ，を変元， エントロピーの手法を用いで精密さの点から，現像能の 評価を行なった。

〔結果】 実験 1 処理時間による相違. 伝達効率は90 秒処理で濃度範革 $0.88 \sim 1.30$ で $80.4 \%, 3.5$ 分处理で濃 度範国 $0.87 \sim 1.29 て ゙ 82.1 \%$ ．垁験 2 ，自現機の機種に よる相違。伝達効率はそれぞれ $94.6 \% ， 98.9 \% ， 80.3 \%$ 実験 3 現像温度による相違. 伝達效率は $29^{\circ} \mathrm{C}$ で $85.8 \%$, $31^{\circ} \mathrm{C}$ で $87.3 \%, 33^{\circ} \mathrm{C}$ で $91.7 \%, 35^{\circ} \mathrm{C}$ で $93.1 \%, 37^{\circ} \mathrm{C}$ で $92.1 \%$.

〔結語〕伝達效率から考无ると，3.5分処理がすぐれ 